\title{
Students' Needs for Developing English Teaching Materials Based on Islamic Values of Integrated Language Skills for Islamic Elementary School
}

\author{
Savitri Rahmadany ${ }^{1 *}$, Rahmad Husein ${ }^{2}$, Masitowarni Siregar ${ }^{3}$
}

\begin{abstract}
${ }^{1}$ Department of English Applied Linguistics, Universitas Negeri Medan, Sumatera Utara 20221, Medan, Indonesia
${ }^{2}$ Department of English Applied Linguistics, Universitas Negeri Medan, Sumatera Utara 20221, Medan, Indonesia

${ }^{3}$ Department of English Applied Linguistics, Universitas Negeri Medan, Sumatera Utara 20221, Medan, Indonesia

*Corresponding author. Email: savitrirahmadany@gmail.com
\end{abstract}

\begin{abstract}
This study aimed to analyze the fourth-grade students' needs for developing English teaching materials based on Islamic values of integrated language skills. The quantitative and qualitative methods conduct in this study. The data was collected by questionnaire. There were twenty (20), fourth-grade students as participants of this study. The students' needs in the English teaching material can see in two aspects; target needs (necessities, lacks, and wants) and learning needs (goals, inputs, procedures, setting, learners' role, and teacher's role). The results showed that English teaching materials needed by the students based on Islamic values of integrated language skills. The English teaching materials used were less good. The students need English teaching materials that are easy to follow/understand, have an attractive appearance and color (colorful), and used an Islamic-based picture. Also, it should make the students use English words to communicate as the goal and should participate actively in the teaching and learning process. Thus, the teachers need to know the students' needs on English teaching materials to teach in the Islamic elementary school.
\end{abstract}

Keywords: Students' needs, English teaching materials, Islamic values of integrated language skills, Islamic elementary school.

\section{INTRODUCTION}

English is one of the foreign languages taught in Indonesia even from kindergarten to senior high school. Although in elementary schools English is a local content subject most schools teach English. It is important to teach English earlier to young learners because it increases the total number of years spent learning the language [1]. It has been widely accepted that teaching English to young learners gains more attention, whether from parents, teachers, or stakeholders. They believe that it gives more benefits. They also rely on the assumption that the sooner they teach English to children, the better the result would be.

Teachers need to understand who young learners are. They are children who are learning English. As novice learners, surely they do not receive the same treatment as teen or adult learners. They have their special characteristics. The implication for English teaching and learning, the learning process should have been planned, implemented, assessed, and supervised by the conditions of the learners.

In learning English, four skills should be mastered by the students [2]. They are listening, speaking, reading, and writing. They are important and interconnected with each other. Considering the age, listening and speaking are the skills that young language learners need to master first. Through these skills, the learners can recognize what the speaker says and how to express their ideas.

On the other hand, teaching English to young learners in Indonesia is quite problematic since English has limited practice in the 2013 curriculum. English is not included in the curriculum. Although it is omitted from the curriculum, English is not banned [3]. The schools may give English as an extracurricular subject. This class can be after school for about one hour. Even so, there is still a possibility for schools that want to add English as an additional subject in their curriculum. One of them is the Islamic Elementary School of Al-Hijrah 2 Deli Serdang. They realized that English is important to be 
taught earlier and useful in the future. They made their syllabus.

SDIT Al-Hijrah 2 Deli Serdang is one of the Islamic elementary schools that have Islamic teaching as its special characteristics. The vision is "Being an excellent school in spiritual, emotional, and intellectual also care of the environment". Based on its vision, SDIT Al-Hijrah 2 's education goal is to develop students who are muttaqien (pious) with intelligence, noble characters, and life skills that are useful for many people. Furthermore, integrated Islamic elementary schools are Islamic schools that offer some knowledge with the Islamic values into the subjects [4]. Therefore, this school tries to fuse the national education curriculum with religious values. The fuse of the curriculum is done by integrating Islamic values into all the subjects including English subjects.

Moreover, integrating Islamic values is not easy because English for children is different from English for adults. Children have a short concentration in their learning when compared to adults [5]. They are also more easily distracted by other typical learners. For these reasons, teachers in elementary schools need to understand the children's needs and apply the theories by their characteristics. The teachers also should provide the existing materials that are sure for their students' needs.

However, some problems appear in the teaching and learning process. Based on the observation by interviewing the English teacher at the Islamic elementary school Al-Hijrah 2 Deli Serdang, the teacher stated that they do not have any special books related to materials for teaching English to young learners in Islamic Elementary Schools. They still use general English as teaching and learning materials that are not by the learning needs of students in Islamic Elementary School. The themes or images contained in the teaching and learning materials also are not Islamic either. The teacher only inserts the Islamic foundation into each material taught. Teachers often feel that the available textbooks are not sufficient to achieve the various objectives associated with language teaching. Also, learning activities were lack. The teacher did not provide variations in the activities. The activities are not challenging enough for young learners' students. The teaching materials only consist of some activities in every unit. There is almost no variation in exercise activity in each unit.

Need Analysis is essential for developing a course because "it forms a rational basis for all the other components of a systematic language curriculum" [6]. The prominent need analysis is an initial step to develop the curriculum [7]. In addition, He also said that need analysis is the systematic collection and evaluation of all subjective and objective records important to outline and validate defensible curriculum purposes that fulfill the language mastering necessities of students within the context of a particular establishment that have an impact on the learning and teaching state affairs. Need analysis is a set of procedures for specifying the parameters of a course of study which include the criteria and rationale for the learner, the sequencing and selection of course content, methodology, course length, and intensity and duration [8]. Need analysis is the process of determining how and what the course is [9]. Need analysis is needs in designing the course.

Thus, those phenomena show that there are limited English teaching materials that meet the students' needs. Therefore, this study is interesting to analyze students' needs and to get a conclusion on students' need on English teaching materials for Islamic elementary schools based on Islamic values of integrated language skills of KTSP (school based-curriculum).

\section{REVIEW OF LITERATURE}

In conducting this study some theories are needed to explain the study.

\subsection{Need Analysis}

There are several models of need analysis recognize by some scholars; (1) Target Situation Analysis; (2) Present Situation Analysis; (3) Hutchinson and Waters Model; (4) Dudley-Evans and St John's Model of Need Analysis.

Target Situation Analysis (TSA) focused on students' needs at the end of the language course [17]. Present Situation Analysis (PSA) showed the gap between the present and the target. PSA explores "to find out the language proficiency of the students when the language course begins and their strengths and weakness [17]. Need as the ability to comprehend and to produce the linguistic features into two categories; target needs and learning needs [10].

\subsection{Kinds of Need Analysis}

Need analysis model is divided into two parts: Target situation needs and learning needs [10].

\subsubsection{Target Needs}

The target needs are what knowledge and abilities the learner will require to perform appropriately in the target situation. Target situation needs related to the learner 'necessities', 'lacks' and 'wants'.

a) Necessities define as the type of needs determined by the demands of the target situation.

b) Lacks are the gap between what the learners know already and what the learners do not know.

c) Wants are what the learners expect about the language area that they want to master.

Moreover, need analysis provides personal information about the learners, language information about the target situation [9]. Professional information about learners, learners' lack, Learners' needs from the course, language learning needs, and the last how to communicate in the target needs.

\subsubsection{Learning Needs}

Learning needs is the gap between the learner's current level of knowledge and skills, and the level of 
knowledge and skills required to perform a task or a set of task. Specification of tasks includes goals, input, activities, teacher roles, learner roles, and settings [11]. These can draw as follows:

a) The Goal is vague general intentions behind any given learning task. Goals relate to a range of general outcomes or directly describe teacher or learner behavior. The goals sometimes are not explicitly stated but they can conclude from the examination of a task.

b) Input refers to the spoken, written, and visual data that the learners work on within the course of completing a task [11]. Input can be in the form of a letter, newspaper, recipe, picture, dialogue, magazine, etc. Those inputs give the learners an imagination and drive them to process the information based on their background knowledge before they go to the activities.

c) Procedures or activities are what learners will do with the input that forms the point of departure for learning tasks.

d) Teacher and learner roles refer to the part that learner and teacher expect to play carrying out learning tasks the social and interpersonal relationship between the participants [11].

e) Settings refer to the classroom arrangements specified or implied on the task and it requires consideration of whether the task is to carry out wholly or partly outside the classroom [11].

Moreover, several reasons for conducting need analysis before starting a course for a group of learners [12] are as follow:

a) To find out what language skills a learner needs to perform a particular role.

b) To help determine if an existing course adequately addresses the needs of potentials students.

c) To determine which students from a group are most in need of training in particular language skills.

d) To identify a change of direction that people in $s$ reference group feel is important.

e) To identify a gap between what students can do and what they need to be able to do.

f) To collect information about particular problems learners are experiencing.

The procedures of collecting information during a need analysis can be selected from among of the following [13]: a) questionnaire; b) self-rating; c) interview; d) meeting; e) observation; f) collecting learner language sample; g) task analysis; h) study case.

Also, determining the focus of the course based on findings from need analysis [14]. The materials design should interpret the learning need to produce appropriate materials.

As a consequence of this situation, the main aim of the present study was to conduct a need analysis to know the student's needs in learning English. The information of the result of this result will be guidance for developing English teaching materials for Islamic Elementary students based on Islamic values of integrated language skills.

\section{RESEARCH METHOD}

In particular, to analysis, the data of this study was used both quantitative and qualitative data analysis. This study was chosen to develop a quality product design to meet the specific materials used at Islamic elementary schools.

The qualitative data was obtained by providing conclusions from the results of questionnaires. It analyzes using the qualitative data analysis model [15]. The quantitative data is obtained from the set of questionnaires in the form of numbers and percentages. It uses to support qualitative data.

\section{RESULT AND DISCUSSION}

A needs analysis was gathered by administrated the questionnaire to the grade four students of Islamic school. They were given the questionnaire, which consisted of fifteen (15) questions. In doing need analysis there are two basic needs, target needs, and learning needs.

\subsection{Target Needs}

In this study, the target needs to aim at gathering information about: (a) necessities, (b) lacks, and (c) wants of the students in English teaching materials in Islamic elementary schools. The results present as follows.

\subsubsection{Necessities}

The result of the views of the students' necessities presents as follows.

Table 1. Students' needs analysis of English teaching materials

\begin{tabular}{|c|c|c|c|c|c|}
\hline No. & Questions & Options & $\mathrm{N}$ & $\mathrm{F}$ & Percentages $(\%)$ \\
\hline \multirow[t]{5}{*}{1.} & \multirow{5}{*}{$\begin{array}{l}\text { What English-based teaching } \\
\text { materials do you need? }\end{array}$} & Islam & 20 & 20 & 100 \\
\hline & & America & 20 & 0 & 0 \\
\hline & & English & 20 & 0 & 0 \\
\hline & & Australia & 20 & 0 & 0 \\
\hline & & Indonesia & 20 & 0 & 0 \\
\hline \multirow[t]{2}{*}{2.} & \multirow{2}{*}{$\begin{array}{l}\text { In your opinion, what topics do } \\
\text { you need in Islamic-based }\end{array}$} & The human relationship with God & 20 & 4 & 20 \\
\hline & & Human-human relations & 20 & 3 & 15 \\
\hline
\end{tabular}




\begin{tabular}{|c|c|c|c|c|c|}
\hline No. & Questions & Options & $\mathrm{N}$ & $\mathrm{F}$ & Percentages $(\%)$ \\
\hline & \multirow[t]{3}{*}{ English teaching materials? } & Akhlatul Kharimah & 20 & 12 & 60 \\
\hline & & Nature/environment & 20 & 1 & 5 \\
\hline & & Others, (write down)... & 20 & 0 & 0 \\
\hline \multirow[t]{5}{*}{3.} & \multirow{5}{*}{$\begin{array}{l}\text { In your opinion, how the } \\
\text { material in English teaching } \\
\text { materials for Islamic-based } \\
\text { schools should be better? }\end{array}$} & $\begin{array}{l}\text { By basic competencies and competency } \\
\text { standards }\end{array}$ & 20 & 0 & 0 \\
\hline & & $\begin{array}{l}\text { Authentic material / that can be found in } \\
\text { everyday life }\end{array}$ & 20 & 2 & 10 \\
\hline & & Material with Islamic concepts & 20 & 8 & 40 \\
\hline & & $\begin{array}{l}\text { The presentation and explanation of the } \\
\text { material are clear }\end{array}$ & 20 & 10 & 50 \\
\hline & & All are correct & 20 & 0 & 0 \\
\hline
\end{tabular}

The data in Table 1. are about the necessities of the students about English teaching materials. There were twenty (20) students or $100 \%$ need teaching materials based on Islam to learn English. It is because the elementary school is the Islamic elementary school base.

For the topic, there were four (4) students or $20 \%$ said they need a human relationship with God. Three (3) students or $15 \%$ need human and human relations. Twelve (12) students or $60 \%$ need Akhlatul Karimah. And the rest one (1) student or 5\% need nature/environment as the topic in the English teaching materials. It is because those topics are related to the Islamic value/context.

For the materials, there were two (2) students or $10 \%$ need authentic material in everyday life. Eight (8) students or $40 \%$ said they need material with Islamic concepts. And ten (10) students or 50\% said they need the material presented and explained clearly in the English teaching material for Islamic elementary school. Because they thought those three choices are the materials that should be in the English teaching materials.

So, $100 \%$ of them agreed that Islamic teaching materials use to learn English. 60\% agreed Akhlatul Kharimah use as the topic of English teaching materials, and $50 \%$ agreed that the material is present and explained clearly.

\subsubsection{Lacks}

The result of the students' lack of English teaching materials for Islamic elementary schools presents as follows.

Table 2. Students' needs analysis of English teaching materials

\begin{tabular}{|c|c|c|c|c|c|}
\hline No. & Questions & Options & $\mathbf{N}$ & $\mathbf{F}$ & Percentages $(\%)$ \\
\hline \multirow[t]{5}{*}{4.} & \multirow{5}{*}{$\begin{array}{l}\text { How good are the English } \\
\text { teaching materials used in SD } \\
\text { IT AL Hijrah 2? }\end{array}$} & Very good & 20 & 0 & 0 \\
\hline & & Good & 20 & 8 & 40 \\
\hline & & Enough & 20 & 1 & 5 \\
\hline & & Less & 20 & 11 & 55 \\
\hline & & Very less & 20 & 0 & 0 \\
\hline \multirow[t]{5}{*}{5.} & \multirow{5}{*}{$\begin{array}{l}\text { How do you understand } \\
\text { English teaching materials? }\end{array}$} & Very understand & 20 & 0 & 0 \\
\hline & & Understand & 20 & 4 & 20 \\
\hline & & Sufficiently understand & 20 & 6 & 30 \\
\hline & & Not really understand & 20 & 9 & 45 \\
\hline & & Do not understand & 20 & 1 & 5 \\
\hline \multirow[t]{5}{*}{6.} & \multirow{5}{*}{$\begin{array}{l}\text { What difficulties did you face } \\
\text { when mastering the material } \\
\text { on English teaching materials? }\end{array}$} & $\begin{array}{l}\text { I don't understand the material in the teaching } \\
\text { material }\end{array}$ & 20 & 5 & 25 \\
\hline & & $\begin{array}{l}\text { I am not interested and feel bored regarding } \\
\text { the teaching materials provided }\end{array}$ & 20 & 1 & 5 \\
\hline & & $\begin{array}{l}\text { Teaching materials do not make students } \\
\text { active }\end{array}$ & 20 & 4 & 20 \\
\hline & & The material seems monotonous & 20 & 2 & 10 \\
\hline & & All are correct & 20 & 8 & 40 \\
\hline
\end{tabular}

The data in Table 2. are about the lack of students' English teaching materials. For the lack of materials, there were eight (8) students or $40 \%$ said the English teaching materials used were good. One (1) student or 5\% said the English teaching materials used were enough. And eleven (11) students or $55 \%$ said the English teaching materials used were less. It is because they think the existing English teaching materials used are not good enough for them.
For the understanding, there were four (4) students or $40 \%$ understand English teaching materials. Six (6) students or $30 \%$ sufficiently understood English teaching materials. Nine (9) students or $45 \%$ have less understand English teaching materials. One (1) student or 5\% not understood at all about English teaching materials. It is because they do not understand the English teaching materials used. 
For the difficulties faced by the students, there were five (5) students or $25 \%$ said that they did not understand the material in the English teaching material. One (1) student or 5\% did not interest and bored regarding the English teaching materials provided. Four (4) students or $(20 \%)$ said the English teaching materials do not make them active. Two (2) students or $10 \%$ said the English teaching material seems monotonous. And eight (8) students or $40 \%$ said all of the choices were the factors they hardly understood about English teaching materials. Because they thought all of those choices were the lack faced in mastering the English teaching materials.
So, $55 \%$ agreed the English teaching materials used in SD IT AL Hijrah 2 Deli Serdang were less good. $45 \%$ of them still having less understanding of English teaching materials, and $40 \%$ agreed that all of the choices were the factors they hardly understood about English teaching materials.

\subsubsection{Wants}

The following table shows the result of the students' want as follows.

Table 3. Students' needs analysis of English teaching materials

\begin{tabular}{|c|c|c|c|c|c|}
\hline No. & Questions & Options & $\mathbf{N}$ & $\mathbf{F}$ & Percentages $(\%)$ \\
\hline \multirow[t]{5}{*}{7.} & \multirow{5}{*}{$\begin{array}{l}\text { In your opinion, which skills are } \\
\text { a priority in English teaching } \\
\text { materials in integrated Islamic } \\
\text { elementary schools? }\end{array}$} & Listening & 20 & 3 & 15 \\
\hline & & Speaking & 20 & 1 & 5 \\
\hline & & Writing & 20 & 1 & 5 \\
\hline & & Reading & 20 & 2 & 10 \\
\hline & & All are correct & 20 & 13 & 65 \\
\hline \multirow[t]{5}{*}{8.} & \multirow{5}{*}{$\begin{array}{l}\text { In your opinion, how the } \\
\text { layout/arrangement of Islamic- } \\
\text { based English teaching materials } \\
\text { should be? }\end{array}$} & Interesting & 20 & 2 & 10 \\
\hline & & Cleanly & 20 & 4 & 20 \\
\hline & & Can motivate me to learn & 20 & 6 & 30 \\
\hline & & $\mathrm{a}, \mathrm{b}$, and c are correct & 20 & 8 & 40 \\
\hline & & Others (write down)... & 20 & 0 & 0 \\
\hline \multirow[t]{5}{*}{9.} & \multirow{5}{*}{$\begin{array}{l}\text { In terms of appearance, I want } \\
\text { English language teaching } \\
\text { materials that ... }\end{array}$} & In it, there are many pictures & 20 & 5 & 25 \\
\hline & & In it, there are many exercises & 20 & 3 & 15 \\
\hline & & Only presents material to be studied & 20 & 0 & 0 \\
\hline & & $\begin{array}{l}\text { Has an attractive appearance and color } \\
\text { (colorful) }\end{array}$ & 20 & 12 & 60 \\
\hline & & Others (write down).... & 20 & 0 & 0 \\
\hline
\end{tabular}

The data in Table 3. are about the wants of the students about English teaching materials. For the skills, there were three (3) students, or $15 \%$ want listening skills as the priority in the English teaching materials. One (1) student or 5\% want speaking as the priority in the English teaching materials. Also, one (1) students or $5 \%$ want writing as the priority in the English teaching materials, $10 \%$ (2 students) want reading as the priority in the English teaching materials, and thirteen (13) students or $65 \%$ wants all of the skills such as listening, speaking, writing, and reading in the as the priority in the English teaching materials. Because they thought all of those skills are the priority skills in mastering the English teaching materials in elementary school that can not be separated.

For the arrangement/layout of the English teaching materials, there were two (2) students or $10 \%$ want interesting English teaching materials. our (4) students or $20 \%$ want the English teaching materials cleanly, six (6) students or $30 \%$ want the English teaching materials that can motivate them to learn, and eight (8) students or $40 \%$ said all of the choices were the arrangements should be in English teaching materials. Because they thought all of those choices are the criteria for a good arrangement/layout of the English teaching materials.
In terms of appearance, there were five (25\%) students who want the English teaching contains many pictures inside. Three (3) students or $15 \%$ want the English teaching materials that there are many exercises inside, and twelve (12) students or 60\% want the English teaching materials that have an attractive appearance and color (colorful). It is because those three choices are the appearance of English teaching materials they want.

So, $65 \%$ of students agreed with all the skills as the priority in the English teaching materials. $40 \%$ agreed that all of the choices were the arrangements should be in English teaching materials, $60 \%$ agreed that the English teaching materials have an attractive appearance and color (colorful).

\subsection{Learning Needs}

The learning needs was aimed at collecting relevant information on: (a) goals; (b) inputs; (c) procedures; (d) setting; (e) learners role; and (f) teacher's role. The results present as follows.

\subsubsection{Goal}

The results present in the following table. 
Table 4. Students' needs analysis of English teaching materials

\begin{tabular}{|c|c|c|c|c|c|}
\hline No. & Questions & Options & $\mathbf{N}$ & $\overline{\mathbf{F}}$ & Percentages (\%) \\
\hline \multirow[t]{5}{*}{10.} & \multirow{5}{*}{$\begin{array}{l}\text { In general, Islamic English } \\
\text { teaching materials should be } \\
\text { able to make me ... }\end{array}$} & $\begin{array}{l}\text { Recognizing English words (parts of } \\
\text { speech) }\end{array}$ & 20 & 5 & 25 \\
\hline & & Use English words to communicate & 20 & 7 & 35 \\
\hline & & $\begin{array}{l}\text { Understand the meaning of words in } \\
\text { English }\end{array}$ & 20 & 5 & 25 \\
\hline & & $\begin{array}{l}\text { Able to write vocabulary in English } \\
\text { correctly }\end{array}$ & 20 & 3 & 15 \\
\hline & & Others, (write down)... & 20 & 0 & 0 \\
\hline
\end{tabular}

The data in Table 4. are about the goal of the students about English teaching materials. There were five (5) students or $25 \%$ said recognize English words (parts of speech) in learning the English teaching material. Seven (7) students or $35 \%$ said they use English words to communicate. Five (5) students or $25 \%$ said to understand the meaning of words in English, and three (3) students, or $15 \%$ said can to write vocabulary in English correctly in learning the English teaching material. It is because all those choices are their objective to study Islamic English teaching materials.
So, $35 \%$ of them agreed that use English words to communicate is the objective of learning English teaching material.

So, $35 \%$ of them agreed that use English words to communicate is the goal of learning English teaching material.

\subsubsection{Input}

The results present in the following table.

Table 5. Students' needs analysis of English teaching materials

\begin{tabular}{|c|c|c|c|c|c|}
\hline No. & Questions & Options & $\mathbf{N}$ & $\mathbf{F}$ & Percentages $(\%)$ \\
\hline \multirow[t]{5}{*}{11.} & \multirow{5}{*}{$\begin{array}{l}\text { In your opinion, is there a need for } \\
\text { an integrated image display by the } \\
\text { Islamic basis in English teaching } \\
\text { materials? }\end{array}$} & It is necessary & 20 & 12 & 60 \\
\hline & & Need & 20 & 5 & 25 \\
\hline & & Sometimes it is necessary & 20 & 3 & 15 \\
\hline & & No need & 20 & 0 & 0 \\
\hline & & Unnecessary & 20 & 0 & 0 \\
\hline
\end{tabular}

The data in table 5. are about the input of the students about English teaching materials. There were twelve (12) students or $60 \%$ said add Islamic-based pictures in English teaching materials. Five (5) students or $25 \%$ said Islamic-based picture in English teaching materials is a need. And three (3) students or $15 \%$ said sometimes it is necessary to add Islamic-based pictures in English teaching materials. It is because they thought the pictures provided in the materials should be Islamicbased English teaching materials.

So, $60 \%$ of them agreed that an Islamic-based picture in English teaching materials is necessary.

\subsubsection{Procedure}

The results present in the following table.

Table 6. Students' needs analysis of English teaching materials

\begin{tabular}{lllllc}
\hline \multirow{2}{*}{ No. } & \multicolumn{1}{c}{ Questions } & \multicolumn{1}{c}{ Options } & N & F & Percentages (\%) \\
\hline \multirow{2}{*}{12.} & $\begin{array}{l}\text { In your opinion, the } \\
\text { English teaching and } \\
\text { learning process should } \\
\text { take place ... }\end{array}$ & By the learning objectives & 20 & 1 & 5 \\
\cline { 2 - 6 } & Participative & 20 & 3 & 15 \\
\cline { 2 - 6 } & Easy to follow/understand & 20 & 16 & 80 \\
\cline { 2 - 6 } & By the development of students & 20 & 0 & 0 \\
\cline { 2 - 6 } & Others (write down)... & 20 & 0 & 0 \\
\hline
\end{tabular}

The data in Table 6. are about the procedures of the students about English teaching materials. There were one (1) student or 5\% English teaching and learning process by the learning objectives. Three (3) students or $15 \%$ answered English teaching and learning process participative. Sixteen (16) students or $80 \%$ said the English teaching and learning process should be easy to follow/understand. It is because they thought those two choices are how the teaching and learning English should take place.
So, $80 \%$ agreed that the preferred English teaching process should be easy to follow/understand.

\subsubsection{Setting}

The results present in the following table. 
Table 7. Students' needs analysis of English teaching materials

\begin{tabular}{|c|c|c|c|c|c|}
\hline No. & Questions & Options & $\mathbf{N}$ & $\mathbf{F}$ & Percentages (\%) \\
\hline \multirow[t]{5}{*}{13.} & \multirow{5}{*}{$\begin{array}{l}\text { I prefer if the assignment system } \\
\text { in English teaching materials is } \\
\text { done in a ... }\end{array}$} & All students & 20 & 0 & 0 \\
\hline & & Individual & 20 & 5 & 25 \\
\hline & & Group & 20 & 8 & 40 \\
\hline & & Couple & 20 & 7 & 35 \\
\hline & & Others (write down)... & 20 & 0 & 0 \\
\hline
\end{tabular}

The data in Table 7. are about the setting of the students about English teaching materials. There were five (5) students or $25 \%$ preferred the assignment system in English teaching materials done individually. Eight (8) students or $40 \%$ preferred the assignment system in English teaching materials done in a group. Seven (7) students or $35 \%$ preferred the assignment system in English teaching materials done in pairs. Because they thought those three choices are the assignment system in English teaching materials should be done.
So, $40 \%$ of them agreed that group as preferred assignment system in English teaching materials.

So, $40 \%$ of them agreed that group as preferred assignment system in English teaching materials.

\subsubsection{Learners Role}

The results present in the following table.

Table 8. Students' needs analysis of English teaching materials

\begin{tabular}{|c|c|c|c|c|c|}
\hline No. & Questions & Options & $\mathbf{N}$ & $\mathbf{F}$ & Percentages $(\%)$ \\
\hline \multirow[t]{5}{*}{14.} & \multirow{5}{*}{$\begin{array}{l}\text { In the process of } \\
\text { delivering English } \\
\text { teaching materials you } \\
\text { should ... }\end{array}$} & Just listen to the explanation of the material & 20 & 4 & 20 \\
\hline & & Record all material submitted & 20 & 7 & 35 \\
\hline & & Participate actively in the learning process & 20 & 9 & 45 \\
\hline & & $\begin{array}{l}\text { Learn by yourself and work on the problems } \\
\text { calmly }\end{array}$ & 20 & 0 & 0 \\
\hline & & Others (write down)... & 20 & 0 & 0 \\
\hline
\end{tabular}

The data in Table 8. are about the learners' role in English teaching materials. There were four (4) students or $20 \%$ said they preferred to just listen to the explanation of the English teaching material. Seven (7) students or $35 \%$ said they preferred to write all English teaching materials presented. Nine (9) students or $45 \%$ said they participate actively in the learning process. Because they thought those three choices were the process of delivering the English teaching materials.
So, $45 \%$ of them agreed that they participate actively in the English teaching and learning process.

\subsubsection{Teacher's role}

The results present in the following table.

Table 9. Students' needs analysis of English teaching materials

\begin{tabular}{|c|c|c|c|c|c|}
\hline No. & Questions & Options & $\mathbf{N}$ & $\mathbf{F}$ & Percentages $(\%)$ \\
\hline \multirow[t]{5}{*}{15.} & \multirow{5}{*}{$\begin{array}{l}\text { In the process of delivering } \\
\text { English teaching materials, } \\
\text { the teacher should.... }\end{array}$} & $\begin{array}{l}\text { Explain and ask students to do practice } \\
\text { questions }\end{array}$ & 20 & 10 & 50 \\
\hline & & $\begin{array}{l}\text { Read the material and interpret it directly with } \\
\text { students }\end{array}$ & 20 & 6 & 30 \\
\hline & & $\begin{array}{l}\text { Circling the class while controlling student } \\
\text { work and making comments }\end{array}$ & 20 & 2 & 10 \\
\hline & & Guide students in discussing material & 20 & 2 & 10 \\
\hline & & Others (write down) ... & 20 & 0 & 0 \\
\hline
\end{tabular}

The data in Table 9 are about the teachers' role of the students in English teaching materials. There were ten (10) students, or $50 \%$ preferred the teacher to explain and ask students to do practice questions. Six (6) students or $30 \%$ preferred the teacher read the material and interpret it directly. Two (2) students or $10 \%$ preferred the teacher to circle the class while controlling student work and making comments, and two (2) students or $10 \%$ preferred the teacher to guide them in discussing the English teaching material. It is because all those choices are the students' perspectives on teachers in delivering English teaching materials.

So, $50 \%$ of them agreed that the teacher to explain and ask students to do practice questions in the English teaching and learning process.

So, $50 \%$ of them agreed that the teacher to explain and ask students to do practice questions in the English teaching and learning process.

Consider the fact, as point out the learners seem to be better motivates about language learning when new and 
exciting materials use [16]. Therefore, the result uses to develop English teaching materials for Islamic elementary schools. The needs analysis conducts by distributing questionnaires to the students. The questionnaires evolve based on the needs analysis theory, [10] covers target needs and learning needs. The target needs cover necessities, lacks, and wants. The learning needs cover input, procedures, setting, learners' role, and teacher's role. All of those components consider as the basis for developing English teaching materials for Islamic elementary schools.

\section{CONCLUSION}

Based on the study, English teaching materials needed by the students are Islamic English teaching materials based on Islamic values of integrated language skills (listening, reading, speaking, and writing). The English teaching materials should be uncomplicated to follow/understand, has an attractive appearance and color (colorful), and used an Islamic-based picture. The English teaching materials also should make the students use English words to communicate and participate actively in the teaching and learning process.

\section{ACKNOWLEDGMENT}

The highest gratitude and thanks go to her two advisors, Dr. Rahmad Husein, M. Ed as her first advisor, and Dr. Masitowarni Siregar, M. Ed. as her second advisor for their all guidance, assistant, encouragement, and valuable suggestions through the completion of this study.

\section{REFERENCES}

[1] J. Brewster, G. Ellis, and D. Girard, The Primary English Teacher's Guide (2nded), London: Penguin Books, 2002.

[2] K.K.E, Suyanto, English for Young Learners, Jakarta: PT Bumi Aksara, 2008.

[3] Undang-Undang No. 20 tentang Sistem Pendidikan Nasional, Jakarta: Depdiknas, 2003.

[4] JSIT Indonesia, Standar Mutu Kekhasan Sekolah Islam Terpadu, Jakarta: Jaringan Sekolah Islam Terpadu, 2014.
[5] L. Cameron, Teaching Language to Young Learner, Cambridge: Cambridge University Press, 2001.

[6] T. Iwai, Kondo, K. Limm, E. G. Ray, H. Shimizu, and J. D. Brown, Japanese language needs analysis, 1999.

[7] J.D. Brown, The elements of Language Curriculum: a Systematic Approach to Program Development, Boston, Massachusetts: Heinle \& Heinle Publisher, 1995.

[8] D. Nunan, The learner-centered curriculum. Cambridge: Cambridge University Press, 1994.

[9] T. Dudley-Evans \& St. John, M. J., Developments in English for Specific Purposes: A multidisciplinary Approach, Cambridge, Cambridge University Press, 1998.

[10] T. Hutchinson and A. Waters, English for Specific Purposes: A Learning-Centered Approach. $6^{\text {th }}$ Edition, Cambridge: University Press, 1987.

[11] D. Nunan, Important Tasks of English Education. Asia-wide and Beyond the Asian EFL, Journal Quarterly, Vol. 7, No. 3, 2004, pp. 5-8.

[12] J. C. Richards and W.A. Renandya, Methodology in Language Teaching: An Anthology of Current Practice, Cambridge: Cambridge University Press, 2002

[13] J. C. Richards and T. S. Rodgers, Approach and Methods in Language Teaching, Cambridge: Cambridge University Press, 2001.

[14] H. Basturkmen, Developing Courses in English for Specific Purposes, London: Palgrave Mac2Millan, 2010 .

[15] M. B. Miles, A. M. Huberman, and J. Saldana, Qualitative Data Analysis: 3rd Edition, Newbury Park: Sage, 2014.

[16] N. Ishihara and Chi, J. C, Authentic Video in the Beginning Classroom: Using a Full-length Feature Film for Listening and Speaking Strategy Practice, English Teaching Forum, Vol. 42, No. 1, 2004, pp. 30-35.

[17] P. Robinson, ESP Today: A Practitioner's Guide, Hemel Hempstead: Prentice-Hall, 1991. 